\title{
Efficacy and safety during formulation switch of a pasteurized VWF/FVIII concentrate: results from an Italian prospective observational study in patients with von Willebrand disease
}

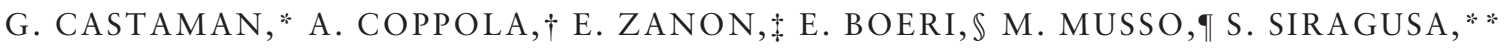

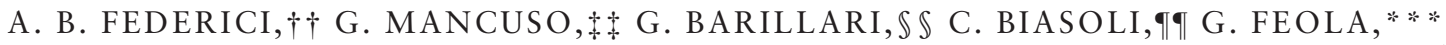

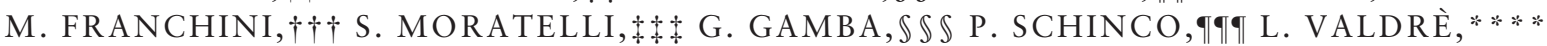

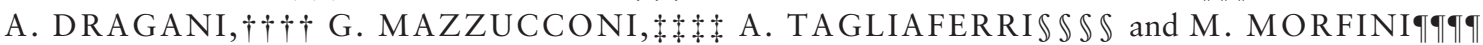 \\ *San Bortolo Hospital, Vicenza, Italy; †Federico II University Hospital, Naples, Italy; $\$$ University Hospital, Padua, Italy; \\ \Gaslini Hospital, Genoa, Italy; $\mid$ University Hospital Catania, Catania, Italy; * University Hospital Palermo, Palermo, Italy; \\ †i IRCCS Cà Granda Maggiore Policlinico Hospital Foundation and Department of Internal Medicine, AB Bonomi \\ Hemophilia Thrombosis Center, University of Milan, Milan, Italy; + t Children's Hospital, Palermo, Italy; $\mathbb{S} \mathbb{S}$ University \\ Hospital, Udine, Italy; $\uparrow \uparrow$ Bufalini Hospital, Cesena, Italy; $* *$ San Luca Hospital, Vallo della Lucania, Italy; †† Istituti \\ Ospitalieri, Verona, Italy; ++ University Hospital, Ferrara, Italy; \$S\$San Matteo Hospital, Pavia, Italy; $\mathbf{q \uparrow | S a n ~ G i o v a n n i}$

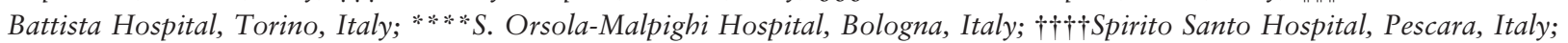 \\ t+t+Umberto I Hospital, Roma, Italy; $\mathbb{S} \mathbb{S} \mathbb{S}$ SUniversity Hospital, Parma, Italy; and $\uparrow \uparrow \uparrow \uparrow$ Careggi Hospital, Florence, Italy
}

Summary. Von Willebrand disease (VWD) is an inherited bleeding disorder caused by the quantitative or qualitative deficiency of von Willebrand factor (VWF). Replacement therapy with plasma-derived VWF/factor VIII (FVIII) concentrates is required in patients unresponsive to desmopressin. To assess the efficacy, safety and ease of use of a new, volume-reduced (VR) formulation of VWF/FVIII concentrate Haemate ${ }^{\circledR} \mathrm{P}$ in patients requiring treatment for bleeding or prophylaxis for recurrent bleeding or for invasive procedures. Pharmacoeconomic variables were also recorded. Data were analysed using descriptive statistics. This was a multicentre, prospective, observational study. Consecutively enrolled patients received $\underline{\text { Haemate }^{\circledR}} \underline{\mathrm{P}} \underline{\mathrm{VR}}$ according to their needs, and were followed for 24 months. Of the 121 patients enrolled, $25.6 \%$ had type 3 VWD and more than $40 \%$ had severe disease. All patients were

\section{Introduction}

Von Willebrand disease (VWD), an inherited bleeding disorder which affects $1-2 \%$ of the general population

Correspondence: Giancarlo Castaman, Department of Cell Therapy and Hematology, Hemophilia and Thrombosis Center, San Bortolo Hospital, Viale Rodolfi 37, 36100 Vicenza, Italy.

Tel.: +39 444 753679; fax: +39 444753922 ;

e-mail: castaman@hemato.ven.it

Accepted after revision 25 July 2012 followed for 2 years, for a total of 521 visits. Ondemand treatment was given to $61.9 \%$ of patients, secondary long-term prophylaxis to $25.6 \%$ and prophylaxis for surgery, dental or invasive procedures to $45.5 \%$. The response to treatment was rated as good to excellent in $>93-99 \%$ of interventions. The new formulation was well tolerated by all patients with no report of drug-related adverse events. The switch to volume-reduced Haemate ${ }^{\circledR} \mathrm{P}$ was easy to perform and infusion duration was decreased twofold compared with the previous formulation. Volume-reduced Haemate ${ }^{\circledR} \mathrm{P}$ was at least as effective and well-tolerated as the previous formulation.

Keywords: formulation switch, Haemate P, observational study, pasteurized VWF/FVIII concentrate, volumereduced infusion, von Willebrand disease
[1-3], is caused by a deficiency or abnormality of the von Willebrand factor (VWF), a multimeric adhesive glycoprotein with a key role for platelet adhesion to occur [3]. The VWF is also the carrier of factor VIII (FVIII), and therefore indirectly contributes to coagulation [3].

The treatment of VWD aims to correct both abnormal platelet adhesion and FVIII deficiency [1] and it can be administered on demand or as prophylaxis in the more severe forms of the disease to control recurrent mucosal and joint bleeding or in the case of invasive procedures $[4,5]$. 
Therapy with desmopressin and replacement therapy with plasma-derived VWF or VWF/FVIII concentrates are the mainstay of VWD treatment [4]. Haemate $^{\circledR}$ P (CSL Behring, Marburg, Germany), a pasteurized VWF/FVIII plasma-derived concentrate in use for almost three decades, has been demonstrated by extensive clinical practice to be an effective and safe treatment for patients with VWD [6,7]. A novel, volume-reduced formulation has been recently developed, maintaining the same characteristics, but with a reduction of $50 \%$ of reconstitution volume which could be useful especially when a high dose of VWF/ FVIII is required in a single infusion [7]. Clinical experience with this novel formulation is limited, and additional information is desirable for a complete evaluation of its efficacy and safety.

To monitor the impact of the switch to this novel concentrate formulation in the context of real-life clinical practice, a prospective, observational study involving 20 Italian Haemophilia Treatment Centres (HTC) was undertaken.

\section{Materials and methods}

\section{Study design}

This survey was a prospective, observational, openlabel study conducted in HTCs located throughout Italy. The objectives of the study were: (i) to monitor clinical efficacy and tolerability during the switch to the volume-reduced VWF/FVIII formulation; (ii) to evaluate prospectively the incidence of spontaneous bleeds and their management in a large population of patients with VWD; (iii) to collect data for pharmacoeconomic analysis; and (iv) to compare the ease of use of the old and the new formulations.

Patient enrolment took place between 2007 (year of introduction of the new formulation) and 2008. Patients were observed for 24 months. The 24-month follow-up started after the administration of the first infusion of the volume-reduced formulation of the VWF/FVIII concentrate. The study was non-interventional and patients were treated with volume-reduced Haemate $^{\circledR}$ P VR (CSL Behring Marburg, Germany)[8] based on their clinical needs, as judged by the investigator. The study was performed in accordance with the Declaration of Helsinki, and its design was approved by local Ethical Committees. All patients provided written consent to their inclusion in the study.

\section{Study population}

Patients with VWD of either gender and of any age were eligible if they had been already treated with Haemate ${ }^{\circledR}$ P. Patients were diagnosed according to the criteria of the Scientific Standardization Committee on VWF of the International Society of Thrombosis and
Haemostasis, and VWD types were determined as previously reported $[1,9]$.

\section{Treatment}

Patients received Haemate ${ }^{\circledR}$ P VR (vials of $500 / 1200$ or 1000/2400 IU of FVIII/VWF:Ristocetin Cofactor (VWF:RCo) to be reconstituted with $10 \mathrm{~mL}$ instead of $20 \mathrm{~mL}$ or $15 \mathrm{~mL}$ instead of $30 \mathrm{ml}$ infusion solution respectively) intravenously. Investigators were asked to follow current treatment guidelines $[1,4]$ and the doses recommended by the manufacturer (VWF:RCo, 40-80 IU kg ${ }^{-1}$ body weight and FVIII:C, $20-40 \mathrm{IU} \mathrm{kg}^{-1}$ body), but no restriction to the investigators' clinical decision was made [8]. The concentrate was given for three distinct situations: (i) as treatment on demand for bleeding episodes; (ii) as secondary long-term prophylaxis; and (iii) as prophylaxis for surgery, dental or invasive procedures. Major surgery was defined as surgery under general anaesthesia and requiring $>4$ days of hospitalization.

\section{Variables recorded}

Each patient was evaluated at the enrolment visit (baseline) and during at least one but not more than four follow-up visits per year. In each centre, all visits were performed by the same trained clinician, to limit inter-operator variability.

Demographic characteristics (including VWD type and gene mutation were available) and detailed medical history (including date of first VWD diagnosis, bleeding history and bleeding score [BS] measured as previously reported [10], bleeding frequency during the last 12 months, previous treatments, total exposure days [ED] to VWF/FVIII concentrates) were collected at enrolment. Increased disease severity correlates with increasing BS: healthy individuals have scores $<3$, whereas $\mathrm{BS} \geq 3$ and $<5$ indicates mild disease, $\mathrm{BS} \geq 5$ and $<10$ indicates moderate disease and BS $\geq 10$ indicates severe disease [10]. At each follow-up visit, the clinical response to Haemate ${ }^{\mathbb{B}} \mathrm{P}$ was assessed by the clinician as recommended by the European Medicines Agency Guideline on the clinical investigation of human plasma-derived VWF products and rated as previously reported $[9,11]$. The response was rated as excellent when it was clinically not different from normal on surgery and invasive procedures, or when optimal and fast control of spontaneous bleeding was achieved; good, when mildly abnormal, partial or delayed control of spontaneous bleeding, or slight transient oozing from surgical wounds; moderate, when moderately abnormal haemostasis bleeding not fully controlled but no need for additional therapy; poor, when no improvement at all with continuation of bleeding and need for additional or alternative therapies [9]. The safety of the treatment was also monitored 
and suspected adverse events related to the treatment were recorded in a standardized case report form. Adverse events were defined as any change from baseline in the patient's health status that occurred within $24 \mathrm{~h}$ of the VWF/FVIII concentrate administration. Additional data, including laboratory tests and pharmacoeconomic variables (work/school days lost; hospitalization; interventions required for the management of haemorrhagic complications) were recorded when available.

\section{Statistical methods}

All data were analysed using descriptive statistics. A prespecified ad interim analysis was planned and conducted on the first 50 patients for whom the data from at least one follow-up visit were available [12].

\section{Results}

\section{Characteristics of the study population}

Demographic and baseline clinical characteristics. In total, 121 patients were enrolled in the study and all were followed-up for 24 months after inclusion. Their baseline characteristics are summarized in Table 1. Type 1 VWD was most prevalent (56/121, 46.3\%), followed notably by type 3 VWD (31/121, 25.6\%), type $2 \mathrm{~B}(22 / 121,18.2 \%)$, type $2 \mathrm{~A}(8 / 121,6.6 \%)$ and type $2 \mathrm{M}(1 / 121,0.8 \%)$ [data on VWD type not available for three $(2.5 \%)$ patients]. At the time of their first study visit, the majority of patients $(83.5 \%)$ were receiving Haemate $^{\circledR} \mathrm{P}$ on-demand, whereas $13.2 \%$ received it for long-term secondary prophylaxis. The median BS was high (severe disease) and homogenous across VWD subtypes (median score of study cohort was 15 , range 2-36). Forty-three per cent of patients had VWF:RCo $<10 \mathrm{IU} \mathrm{dL}^{-1}$ (indicative of severe disease) and in $48.8 \%$ of patients FVIII:C was $\leq 20 \mathrm{IU} \mathrm{dL}^{-1}$ (also indicative of severe disease).

Treatment history. For $61 \%$ of the study cohort, ondemand Haemate $^{\circledR} \mathrm{P}$ had been the only treatment modality, whereas a minority $(6 \%)$ had received only prophylactic Haemate ${ }^{\circledR}$ P. About one-third of the cohort $(33 \%)$ had received treatment both on demand and as prevention (Table 1). Total ED to Haemate ${ }^{\circledR}$ $\mathrm{P}$ up to the first study visit varied among patients, with a tendency to more limited exposure in patients with VWD type 1 compared with the other disease types (> 70\% of type 1 patients with ED 1-24 days). During the last 12 months before entering the study, 42 patients of the entire cohort $(34.7 \%)$ underwent surgery, dental extractions and invasive procedures, with a clinical response scored as excellent or good in $95 \%$ of cases [9]. In the same period, the majority of patients $(75.2 \%)$ had either no bleeding episodes or $<5$ episodes requiring treatment with VWF/FVIII concentrates. Epistaxis occurring in $77.7 \%$ of patients was the most frequent spontaneous haemorrhagic event, followed by gingival bleeding $(54.5 \%)$.

Table 1. Demographic, baseline clinical characteristics and summary of medical history according to VWD type.

\begin{tabular}{|c|c|c|c|c|c|c|}
\hline & $\begin{array}{l}\text { Type } 1 \\
N=56\end{array}$ & $\begin{array}{l}\text { Type 2A } \\
N=8\end{array}$ & $\begin{array}{l}\text { Type } 2 \mathrm{~B} \\
N=22\end{array}$ & $\begin{array}{l}\text { Type } 2 \mathrm{M} \\
N=1\end{array}$ & $\begin{array}{l}\text { Type } 3 \\
N=31\end{array}$ & $\begin{array}{l}\text { Total } \\
N=121^{\$}\end{array}$ \\
\hline \multicolumn{7}{|l|}{ Gender } \\
\hline Male & $23(41.1 \%)$ & $5(62.5 \%)$ & $10(45.5 \%)$ & $1(100 \%)(-)$ & $12(38.7 \%)$ & $53(43.8 \%)$ \\
\hline Female & $33(58.9 \%)$ & $3(37.5 \%)$ & $12(54.5 \%)$ & - & $19(61.3 \%)$ & $68(56.2 \%)$ \\
\hline Age, years, median [range] & $48.5[5-79]$ & $41.5[21-71]$ & $30.0[9-61]$ & $68.0[-]$ & $31.0[1-73]$ & $41.0[1-79]$ \\
\hline \multicolumn{7}{|c|}{ Diagnostic tests, IU $\mathrm{dL}^{-1}$, median [range] } \\
\hline VWF:RCo & $12.8[<6-50]^{\ddagger}$ & $8[<6-35]$ & $10[<6-28]$ & 8 & $<6[<6-8]^{\star}$ & $8[<6-50]$ \\
\hline FVIII:C & $36[3-89.7]$ & $42[8.7-85]$ & $27[18-58]$ & $110[-]$ & $5[0.3-26.8]$ & $20.35[3-110]$ \\
\hline VWF:Ag & $23[6-55]$ & $31[10-58]$ & $36[26-81]$ & $116[-]$ & $1[1-12]$ & $12.15[1-116]$ \\
\hline \multicolumn{7}{|l|}{ Type of treatment with Haemate ${ }^{\circledR} P^{*}$} \\
\hline On-demand & $52(92.9 \%)$ & $7(87.5 \%)$ & $17(77.3 \%)$ & $1(100 \%)$ & $21(67.7 \%)$ & $101(83.5 \%)$ \\
\hline Prophylaxis & $2(3.6 \%)$ & $1(12.5 \%)$ & $4(18.2 \%)$ & $0(0 \%)$ & $9(29 \%)$ & $16(13.2 \%)$ \\
\hline Not available & $2(3.6 \%)$ & $0(0 \%)$ & $1(4.5 \%)$ & $0(0 \%)$ & $1(3.2 \%)$ & $4(3.3 \%)$ \\
\hline Bleeding score, median [range] & $14[2-29]$ & $14.5[7-25]$ & $20[7-32]$ & $21[-]$ & $18[4-36]$ & $15[2-36]$ \\
\hline \multicolumn{7}{|c|}{ Patients with total ED to VWF/FVIII concentrates } \\
\hline $1-4$ & $12(21.4 \%)$ & $2(25 \%)$ & $3(13.6 \%)$ & - & $5(16.1 \%)$ & $23(19 \%)$ \\
\hline $5-24$ & $31(55.4 \%)$ & $1(12.5 \%)$ & $3(13.6 \%)$ & - & $5(16.1 \%)$ & $41(33.9 \%)$ \\
\hline $25-49$ & $3(5.4 \%)$ & $1(12.5 \%)$ & $1(4.5 \%)$ & - & $2(6.5 \%)$ & $7(5.8 \%)$ \\
\hline $50-\geq 150$ & $10(17.9 \%)$ & $4(50 \%)$ & $14(63.6 \%)$ & $1(100 \%)$ & $19(61.3 \%)$ & $48(39.7 \%)$ \\
\hline NA & $0(0 \%)$ & $0(0 \%)$ & $1(4.5 \%)$ & - & $0(0 \%)$ & $2(1.7 \%)$ \\
\hline \multicolumn{7}{|c|}{ Patients with bleedings during last 12 months $^{\dagger}$} \\
\hline $0-4$ bleeds & $48(85.7 \%)$ & $7(87.5 \%)$ & $15(68.2 \%)$ & - & $19(61.3 \%)$ & $91(75.2 \%)$ \\
\hline $5-19$ & $2(3.6 \%)$ & $1(12.5 \%)$ & $7(31.8)$ & $1(100 \%)$ & $8(25.8 \%)$ & $20(16.5 \%)$ \\
\hline $20-\geq 50$ & $1(1.8 \%)$ & - & - & - & $4(12.9 \%)$ & $5(4.1 \%)$ \\
\hline NA & $5(8.9 \%)$ & & & & - & $5(4.1 \%)$ \\
\hline
\end{tabular}

\footnotetext{
"Bleedings requiring treatment with VWF/FVIII concentrates.

†At presentation/study entry.

Some patients on prophylaxis at time of enrolment.

${ }^{\$}$ VWD type not available for three patients.

ED, days of exposure.
} 
Switch to Haemate ${ }^{\circledR}$ P VR. A total of 521 follow-up visits took place during the 24 months of observation. The concentrate was administered in $44 \%$ of these visits by hospital staff, whereas in only $20 \%$ of the visits was the concentrate self-administered by the patient. Handling of the new concentrate formulation was easy and required a median time of $10 \mathrm{~min}$ both for reconstituting the concentrate and for injecting it (approximately half the time normally required for infusion of the previously available formulation). Haemate $^{\circledR} \mathrm{P}$ VR was given on demand to $61.9 \%$ of all patients (75/121), as secondary prophylaxis to $25.6 \%(31 / 121)$ and for surgical, dental or invasive procedures to $45.5 \%(55 / 121)$.

Treatment on-demand. Of the 75 patients who were given volume-reduced Haemate ${ }^{\circledR} \mathrm{P}$ on demand, 49 received only this treatment modality whereas 26 received also long-term prophylaxis. The data regarding on-demand treatment are summarized in Table 2. A total of 677 bleeding events (median four events/ patient, range 1-55) were treated with a total of 1495 infusions (median 13 infusions/patient, range 1-121). The median number of infusions required for each event was one (range 1-28). The response to Haemate ${ }^{\circledR} \mathrm{P}$ was excellent in 316 treatments $(46.9 \%)$, good in $327(48.5 \%)$, moderate in $25(3.7 \%)$, whereas no response was reported in one case $(0.1 \%)$ [response data not available for $5(0.7 \%)$ patients]. Of the 677 bleeding episodes recorded in patients treated on-demand, the most frequent were epistaxis $(203 /$ $677,30 \%$ ) followed by gingival bleeding (126/677, $18.6 \%)$, bleeding in joints $(119 / 677,17.6 \%)$, menorrhagia $(104 / 677,15.4 \%)$ and gastrointestinal bleeding $(64 / 677,9.5 \%)$.

Secondary long-term prophylaxis. The patients receiving prophylactic treatment with Haemate $^{\mathbb{B}}$ P VR (31/ $121,25.6 \%$ ) had a total of 127 events $\overline{\text { during }}$ the 24 months of follow-up (median three events per patient, range 1-11). The data regarding this treatment modality are shown in Table 3. A regimen of $20 \mathrm{IU} \mathrm{kg}^{-1}$ FVIII twice or thrice weekly was used in about $90 \%$ of cases. The total number of infusions was 2850 and the median number of infusions per patient was 63 (range 6-308; median of 22 infusions per event, range $1-104)$. Each patient received $112 \times 10^{3} \mathrm{IU}$ Haemate $^{\circledR} \mathrm{P}$ (median value, range 9-843 $\times 10^{3} \mathrm{IU}$ ). The most frequent reasons that prompted the initiation of prophylaxis were prevention of bleeding in joints (41 events), gastrointestinal bleedings (34 events) and menorrhagia (17 events) (Fig. 1). Overall, the response to treatment was good to excellent in 118/127 (92.9\%) cases whereas in only $6 / 127(6.3 \%)$ was the response rated as moderate and poor (Table 4$)$.

Prophylaxis for surgery, dental extractions, invasive procedures. During the 24-month observation, 55 patients underwent surgery, dental extractions and other invasive procedures (total number of interventions,

Table 2. On-demand treatment* : characteristics of therapeutic interventions with Haemate ${ }^{\circledR}$ P VR in the overall study cohort and according to VWD types.

\begin{tabular}{|c|c|c|c|c|c|c|}
\hline & Type 1 & Type 2A & Type 2B & Type $2 \mathrm{M}$ & Type 3 & Total \\
\hline N. receiving on-demand treatment & $29(38.7 \%)$ & $5(6.7 \%)$ & $14(18.7 \%)$ & $1(1.3 \%)$ & $25(33.3 \%)$ & $75(100 \%)$ \\
\hline Total events & 131 & 17 & 150 & 10 & 365 & $674 *$ \\
\hline Events per patient, median [range] & $2[1-40]$ & $3[1-6]$ & $7.5[2-39]$ & 10 & $6[1-55]$ & $4[1-55]$ \\
\hline Infusions per event, median [range] & $1[1-26]$ & $2[1-18]$ & $2[1-12]$ & $3[1-14]$ & $1[1-28]$ & $1[1-28]$ \\
\hline \multicolumn{7}{|l|}{ Clinical response } \\
\hline Excellent & $95(72.5 \%)$ & $9(52.9 \%)$ & $87(58 \%)$ & $10(100 \%)$ & $115(31.5 \%)$ & $316(46.9 \%)$ \\
\hline Good & $36(27.5 \%)$ & $7(41.2 \%)$ & $55(36.7 \%)$ & - & $228(62.5 \%)$ & $327(48.5 \%)$ \\
\hline NA & - & $1(5.9 \%)$ & $2(1.3 \%)$ & - & $2(0.5 \%)$ & $5(0.7 \%)$ \\
\hline
\end{tabular}

*Total number of events treated was 677 , but for three events disease type was unknown.

Table 3. Prophylaxis: characteristics of therapeutic interventions with Haemate ${ }^{\circledR}$ P VR in the overall study cohort and according to VWD types.

\begin{tabular}{|c|c|c|c|c|c|}
\hline & Type 1 & Type $2 \mathrm{~A}$ & Type 2B & Type 3 & Total \\
\hline N. receiving prophylaxis & $9(29 \%)$ & $1(3.2 \%)$ & $516.1 \%)$ & $16(51.6 \%)$ & $31(100 \%)$ \\
\hline Total events & 25 & 10 & 29 & 63 & 127 \\
\hline Events per patient, median [range] & $2[1-5]$ & 10 & $5[2-10]$ & $2[1-11]$ & $3[1-11]$ \\
\hline Total infusions & 680 & 308 & 404 & 1458 & 2850 \\
\hline Infusions per patient, median [range] & $42[26-244]$ & 308 & $63[21-185]$ & 88.5 [6-207] & $63[6-308]$ \\
\hline Infusions per event, median [range] & $19[3-84]$ & $31[16-61]$ & $18[3-50]$ & $24[1-104]$ & $22[1-104]$ \\
\hline Haemate $^{(8)} \mathrm{P}$ per event, IU $\times 10^{3}$, median [range] & $42[6-168]$ & $74[32-169]$ & $24[6-150]$ & $22[3-144]$ & $30[3-169]$ \\
\hline \multicolumn{6}{|l|}{ Clinical response } \\
\hline Excellent & $12(48 \%)$ & $3(30 \%)$ & $13(44.8 \%)$ & $21(33.3 \%)$ & $49(38.6 \%)$ \\
\hline Good & $13(52 \%)$ & $6(60 \%)$ & $14(48.3 \%)$ & $36(57.1 \%)$ & $69(54.3 \%)$ \\
\hline Moderate/Poor & - & $1(10 \%)$ & $2(6.9 \%)$ & $5(7.9 \%)$ & $8(6.3 \%)$ \\
\hline NA & - & - & - & $1(1.6 \%)$ & $1(0.8 \%)$ \\
\hline
\end{tabular}


126) and therefore received Haemate $^{\circledR} P$ VR as shortterm prophylaxis. The procedures were mostly dentistry interventions $(52.1 \%)$ and invasive procedures/ endoscopy $(25.6 \%)$. The concentrate (infusion of $4 \times 10^{3} \mathrm{IU}$ per event, median; $12 \times 10^{3} \mathrm{IU}$ per patient, median) was given 60 min (median) before the procedure and after surgery (timing of postoperative treatment was dependent on surgery type and patient bleeding tendency) [Table 4]. These patients received a total of 234 postoperative, surgery-related infusions (median 7.0 per patient, range 1-19). The median number of postoperative infusions required to treat one event was five (range 1-16). In this subgroup of patients, most events were treated successfully with a response rated as excellent in 56.7\% of the events treated (only one patient, with VWD type $2 \mathrm{~A}$, had a moderate response to treatment) [Table 4].

Tolerability and safety of the switch. The treatment with Haemate ${ }^{\circledR} \mathrm{P}$ was generally well-tolerated during the 24-month observation after the switch to the volume-reduced formulation of Haemate ${ }^{\circledR} \mathrm{P}$. There were

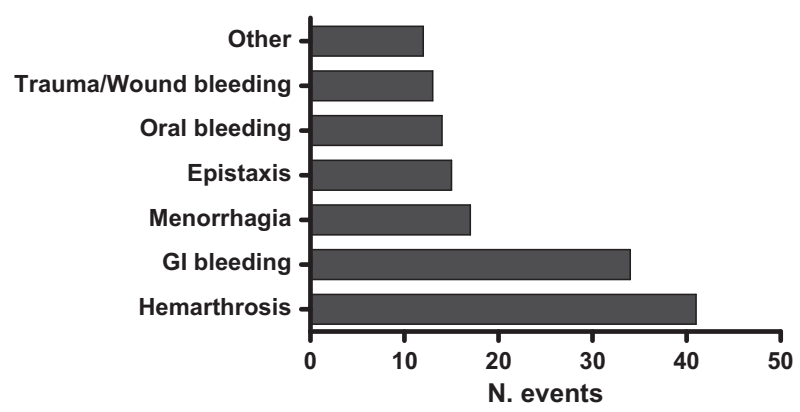

Fig. 1. Events leading to the decision to give prophylactic Haemate ${ }^{\circledR} \mathrm{P}$ to the patients in the subgroup treated with prophylaxis. no reports of adverse reactions related to the study drug or development of inhibitors against VWF in the entire population, including patients on secondary prophylaxis and thus receiving more infusions. No thrombotic events were reported.

Impact of VWD on patient productivity and resource use. During the 24-month follow-up period, almost half of the patients missed days at school/work because of VWD, $36.4 \%$ were hospitalized and $35.5 \%$ underwent surgery because of the disease (Table 5).

\section{Discussion}

The efficacy and safety of Haemate ${ }^{\circledR} \mathrm{P}$ for the treatment of VWD in a setting of real-life clinical practice have so far been addressed in a number of retrospective and prospective studies [9,13-17]. To our knowledge, however, this is the first prospective study on a large (121 patients) population of patients with VWD receiving Haemate ${ }^{\mathbb{B}} \mathrm{P}$ to treat a bleeding episode, as long-term prophylaxis or as short-term prophylaxis for surgery. Treatment history and dosing information was very detailed, and data on patients undergoing surgery/invasive procedures, a treatment setting still under intense investigation, were also collected. Also, the population considered was quite unique in terms of VWD-type distribution, as a relatively high proportion of patients had disease type 3 (31/121), a low prevalence subgroup in the general population of patients with VWD and most severely predisposed to bleeding events due to the virtual absence of VWF $[2,3]$. The study population was also assessed in terms of BS, a parameter useful for the objective assessment of disease severity and for guiding therapeutic choices. The high average BS observed clearly indicates that a large proportion of the recruited patients had a

Table 4. Characteristics of therapeutic interventions with Haemate ${ }^{\circledR}$ P VR in the patients who underwent surgery, dental extractions or other invasive procedures.

\begin{tabular}{|c|c|c|c|c|c|c|}
\hline & Type 1 & Type $2 \mathrm{~A}$ & Type 2B & Type $2 \mathrm{M}$ & Type 3 & Total \\
\hline N. receiving treatment & $26(47.3 \%)$ & $6(10.9 \%)$ & $8(14.5 \%)$ & $1(1.8 \%)$ & $12(21.8 \%)$ & $55 *(100 \%)$ \\
\hline Total events & 70 & 10 & 18 & 2 & 20 & 127 \\
\hline $\begin{array}{l}\text { Events per patient, } \\
\text { median [range] }\end{array}$ & $1.5[1-12]$ & $1[1-4]$ & $1[1-6]$ & 2 & $1[1-4]$ & $1[1-12]$ \\
\hline $\begin{array}{l}\text { Infusions per event }{ }^{\dagger}, \\
\text { median [range] }\end{array}$ & $3.5[1-12]$ & $14[2-16]$ & $5.5[2-12]$ & 14 & $6.5[3-12]$ & $5[1-16]$ \\
\hline $\begin{array}{l}\text { VWF:RCo, IU kg }{ }^{-1} \text { day }^{-1} \text {, } \\
\text { median [range] }\end{array}$ & $30.77[5-810]$ & $55.84[8.5-89.6]$ & $47.91[23-574.1]$ & $50.98[29-73]$ & $49.48[19.2-95.2]$ & $40.27[5-810.8]$ \\
\hline \multicolumn{7}{|l|}{ Clinical response } \\
\hline Excellent & & & & & & $86(84.3 \%)$ \\
\hline Good & & & & & & $13(12.7 \%)$ \\
\hline Moderate & & & & & & $1(0.9 \%)$ \\
\hline NA & & & & & & $2(1.9 \%)$ \\
\hline
\end{tabular}

"Including two patients with unknown disease type.

${ }^{\dagger}$ Only postoperative infusions.

${ }^{\$}$ Based on 102 clinical response evaluation sheets. 
Table 5. Impact of VWD on patient productivity and resource use during the 24 months of follow-up.

\begin{tabular}{lc}
\hline & Total cohort $(\mathrm{N}=121)$ \\
\hline Absence from work/school due to VWD & \\
Yes & $56(46.3 \%)$ \\
No & $62(51.2 \%)$ \\
NA & $3(2.5 \%)$ \\
Hospitalization due to VWD & $44(36.4 \%)$ \\
Yes & $75(62 \%)$ \\
No & $2(1.7 \%)$ \\
NA & \\
Invasive procedures or surgery due to VWD & $43(35.5 \%)$ \\
Yes & $76(62.8 \%)$ \\
No & $2(1.7 \%)$ \\
NA & \\
Physiotherapy due to VWD & $8(6.6 \%)$ \\
Yes & $111(91.7 \%)$ \\
No & $2(1.7 \%)$ \\
NA & \\
\hline
\end{tabular}

significant bleeding tendency, thus strengthening the relevance of the observed results.

One of the objectives of the study was to monitor the efficacy of a new volume-reduced formulation of Haemate ${ }^{\circledR} \mathrm{P}$, introduced in 2007 . The treatment with this formulation was proved effective overall in the three treatment modalities considered, and the majority of patients including patients with type 3 VWD achieved haemostatic responses rated as 'good' to 'excellent', with no significant differences between disease subtypes. These results confirmed those of a preplanned ad interim analysis of the study [12]. The new formulation was therefore at least as effective as the previous one, also associated with clinical responses rated excellent/good in the majority of patients $[9,13-17]$. Our efficacy findings were also in line with those of recently published studies with other commercially available VWF/FVIII concentrates [18-20].

During the 24-month follow-up period, there was an increase in the number of patients receiving Haemate ${ }^{\circledR}$ P VR for long-term prophylaxis $(n=31) \overline{\mathrm{com}^{-}}$ pared with those on prophylaxis at baseline $(n=16)$. The role of prophylaxis with VWF/FVIII concentrates in VWD is still a matter of debate. So far, few studies have evaluated the use of secondary prophylaxis in VWD. [21-27]. In the study by Berntorp et al. [23] in 35 patients with VWD, mostly with type 3 VWD, prophylaxis was associated with a substantial decrease in the annual number of bleeding events $[23,24]$. Also, patients who started prophylaxis at a young age had no joint bleeds and no clinical signs of arthropathy. Similar results were obtained in a recently published cohort study in 32 patients with a median prophylaxis duration of 3 years leading to the resolution of recurrent bleeding in 31 of the 32 patients [21]. Our results show that prophylactic treatment

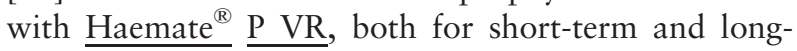

term bleeding prevention, was effective across all disease subtypes.

To our knowledge, the treatment of VWD has not been evaluated in pharmacoeconomic analysis so far. This type of analysis is strongly needed and is likely to contribute also to establishing the role of longterm prophylaxis in the treatment of VWD. We thus collected data describing the impact of VWD on a set of pharmacoeconomic variables. During the 24month follow-up almost half of the patients lost days of school or work and about one-third was hospitalized because of the disease, whereas another third underwent invasive procedures made necessary by the condition. As no previous studies have addressed this aspect it is difficult to make any comparison. However, these figures are in keeping with the presence of significant bleeding histories and morbidity, as shown by the high average BS observed at enrolment.

Haemate ${ }^{\circledR}$ P VR was well-tolerated and the switch to this new formulation was not associated with any serious or unexpected adverse event, including thromboembolic events or inhibitor development, in agreement with previous findings [12]. Thus, the new formulation had a safety profile at least as favourable as the previous one $[9,13-17]$, in all treatment settings, regardless the disease subtypes.

The average time required for infusion was, as expected, approximately twofold shorter than the previous formulation and thus, it is particularly convenient in those patients requiring a high dose in a single infusion, or repeated infusions. The concentrate was still mostly injected by hospital staff, but the increased ease of use of the new formulation will encourage patient self-administration. Time and effort should be dedicated to patients and caregivers' education to home treatment, which enables a prompt and more effective treatment of bleeding episodes and facilitates implementation of prophylaxis, as widely shown in haemophilia patients. [28,29] The diffusion of treatment self-administration at home is likely to improve the quality of life of patients with VWD, which is significantly worse than that of the general population as shown by a recent study in over 500 patients with VWD [30]. Ongoing studies are analysing the cost-effectiveness of this VWF/FVIII concentrate formulation, particularly in the setting of prophylactic treatment.

\section{Acknowledgements}

This study was supported by CSL Behring S.p.A., Italy. G. Castaman obtained lecture fees from CSL Behring. A. Coppola obtained speaker or consulting fees from Baxter, Bayer, CSL Behring and Novo Nordisk. E. Zanon obtained speaker or consulting fees from Baxter, CSL Behring, Grifols, Novo Nordisk and Pfizer. C. Biasoli obtained board participation fee from Novo Nordisk and a reimbursement for participating to a symposium from Bayer. 


\section{Disclosures}

P. Schinco obtained consultant fees or research funding for haemophiliarelated studies from Bayer, Baxter, Pfizer-Wyeth and Novo Nordisk. M.
Morfini obtained consultant and speaker fees from Bayer, Baxter, CSL Behring, Novo Nordisk and Pfizer. Editorial assistance for translation, manuscript preparation and native English editing was provided by InScience Communications, Springer Healthcare. This assistance was funded by CSL Behring.

\section{References}

1 Federici AB, Castaman G, Mannucci PM, for the Italian Association of HemophiliaCenters (AICE). Guidelines for the diagnosis and management of von Willebrand disease in Italy. Haemophilia 2002;8: 607-21.

2 Mannucci PM. Treatment of von Willebrand's disease. N Engl J Med 2004; 351: 683-94.

3 Castaman G, Federici AB, Rodeghiero F, Mannucci PM. Von Willebrand's disease in the year 2003: towards the complete identification of gene defects for correct diagnosis and treatment. Haematologica 2003; 88: 94-108.

4 Mannucci PM, Franchini M, Castaman G, Federici AB, Italian Association of Hemophilia Centers. Evidence-based recommendations on the treatment of von Willebrand disease in Italy. Blood Transfus 2009; 7: 117-26.

5 Franchini M. Surgical prophylaxis in von Willebrand's disease: a difficult balance to manage. Blood Transfus 2008; 6(Suppl 2): S33-8.

6 Schramm W. Haemate P von Willebrand factor/factor VIII concentrate: 25 years of clinical experience. Haemophilia 2008; 14 (Suppl 5): 3-10.

7 Berntorp E. Haemate P/Humate-P: a systematic review. Thromb Res 2009; 124 (Suppl 1): S11-4.

8 SPC of Haemate ${ }^{\circledR}$ P. Available online from URL: http://www.cslbehring.it/docs/229/203/ RCP_Haemate\%20P,0.pdf. Accessed January 21, 2012.

9 Federici AB, Castaman G, Franchini M et al. Clinical use of Haemate ${ }^{\circledR} \mathrm{P}$ in inherited von Willebrand's disease: a cohort study on 100 Italian patients. Haematologica 2007; 92: 944-51.

10 Tosetto A, Rodeghiero F, Castaman G et al. A quantitative analysis of bleeding symptoms in type 1 von Willebrand disease: results from a multicenter European study (MCMDM-1 VWD). J Thromb Haemost 2006; 4: 766-73.

11 EMA Guideline on the clinical investigation of human plasma derived von Willebrand factor products (CPMP/BPWG/220/02), available at: http://www.ema.europa.eu/docs/en_GB/
document_library/Scientific_guideline/2010/ 01/WC500067126.pdf. Accessed July 10, 2012.

12 Morfini M, Coppola A, Zanon E et al. Interim analysis of a prospective observational study on Italian VWD patient, monitoring efficacy and safety during a formulation switch of a pasteurized FVIII/ VWF concentrate. J Thromb Haemost 2009; 7(Suppl 2). abstract n. PP-TH-622.

13 Lillicrap D, Poon MC, Walker I, Xie F, Schwartz BA. Efficacy and safety of the factor VIII/von Willebrand factor concentrate, Haemate-P/Humate $\mathrm{P}$ : ristocetin cofactor unit dosing in patients with von Willebrand disease. Thromb Haemost 2002; 87: 224-30.

14 Franchini M, Rossetti G, Tagliaferri A et al. Efficacy and safety of factor VIII / von Willebrand's factor concentrate (Haemate-P) in preventing bleeding during surgery or invasive procedures in patients with von Willebrand disease. Haematologica 2003; 88: 1279-83.

15 Cox Gill J, Ewenstein BM, Thompson AR et al. Successful treatment of urgent bleeding in von Willebrand disease with factor VIII/VWF concentrate (Humate-P): use of the ristocetin cofactor assay (VWF: $\mathrm{RCo})$ to measure potency and to guide therapy. Haemophilia 2003; 9: 688-95.

16 Thompson AR, Gill JC, Ewenstein BM et al. Successful treatment for patients with von Willebrand disease undergoing urgent surgery using factor VIII/VWF concentrate (Humate-P). Haemophilia 2004; 10: $42-51$.

17 Lethagen S, Kyrle PA, Castaman G et al. von Willebrand factor/factor VIII concentrate (Haemate $\mathrm{P}$ ) dosing based on pharmacokinetics: a prospective multicentre trial in elective surgery. J Thromb Haemost 2007; 5: $1420-30$.

18 Dunkley S, Baker RI, Pidcock M et al. Clinical efficacy and safety of the factor VIII/von Willebrand factor concentrate BIOSTATE in patients with von Willebrand's disease: a prospective multi-centre study. Haemophilia 2010; 16: 615-24.

19 Howman R, Barnes C, Curtin J et al. The clinical efficacy and safety of the FVIII/ VWF concentrate BIOSTATE ${ }^{\circledR}$ in children with von Willebrand disorder: a multicentre retrospective review. Haemophilia 2011; 17: 463-9.

20 Windyga J, Von Depka-Prondzinski M, European Wilate ${ }^{\circledR}$ Study Group. Efficacy and safety of a new generation von Willebrand factor/factor VIII concentrate $\left(\right.$ Wilate ${ }^{\circledR}$ ) in the management of perioperative haemostasis in von Willebrand disease patients undergoing surgery. Thromb Haemost 2011; 105: 1072-9.

21 Halimeh S, Krümpel A, Rott $\mathrm{H}$ et al. Long-term secondary prophylaxis in children, adolescents and young adults with von Willebrand disease Results of a cohort study. Thromb Haemost 2011; 105: 597-604.

22 Oldenburg J. Prophylaxis in bleeding disorders. Thromb Res 2011; 127(Suppl 1): S14-7.

23 Berntorp E, Petrini P. Long-term prophylaxis in von Willebrand disease. Blood Coagul Fibrinolysis 2005; 16: S23-6.

24 Berntorp E. Prophylaxis in von Willebrand disease. Haemophilia 2008; 14(Suppl 5): 47-53.

25 Federici AB, Gianniello F, Canciani MT, Mannucci PM. Secondary long-term prophylaxis in severe patients with von Willebrand's disease: an Italian cohort study. Blood 2005; 106: 507a., abstract 1782.

26 Federici AB. Prophylaxis of bleeding episodes in patients with von Willebrand's disease. Blood Transfus 2008; 6(Suppl 2): s26-32.

27 Lethagen S. Clinical experience of prophylactic treatment in von Willebrand disease. Thromb Res 2006; 118(Suppl 1): S9-11.

28 Schrijvers LH, Beijlevelt-van der Zande M, Peters M, Schuurmans MJ, Fischer K. Learning intravenous infusion in haemophilia: experience from the Netherlands. Haemophilia 2012; 18: 516-20.

29 Colvin BT, Astermark J, Fischer K et al. Inter Disciplinary Working Group. European principles of haemophilia care. Haemophilia 2008; 14: 361-74.

30 De Wee EM, Mauser-Bunschoten EP, Van der Bom JG et al. Health-related quality of life among adult patients with moderate and severe von Willebrand disease. I Thromb Haemost 2010; 8: 1492-9. 